\title{
Covid-19 and public service media: Impact of the pandemic on public television in Europe
}

\author{
Miguel Túñez-López; Martín Vaz-Álvarez; César Fieiras-Ceide
}

Nota: Este artículo se puede leer en español en:

http://www.elprofesionaldelainformacion.com/contenidos/2020/sep/tunez-vaz-fieiras_es.pdf

How to cite this article:

Túñez-López, Miguel; Vaz-Álvarez, Martín; Fieiras-Ceide, César (2020). “Covid-19 and public service media: Impact of the pandemic on public television in Europe". Profesional de la información, v. 29, n. 5, e290518. https://doi.org/10.3145/epi.2020.sep.18

Manuscript received on $16^{\text {th }}$ June 2020 Accepted on $11^{\text {th }}$ August 2020

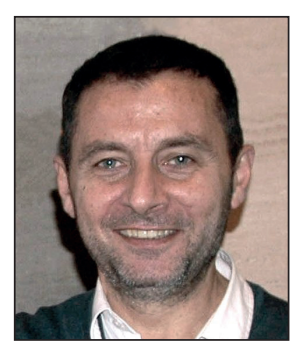

Miguel Túñez-López
https://orcid.org/0000-0002-5036-9143

Universidade de Santiago de Compostela, Facultad de Ciencias de la Comunicación, Depto. de Ciencias de la Comunicación Av. de Castelao, s/n. Campus Norte 15782 Santiago de Compostela, Spain miguel.tunez@usc.es

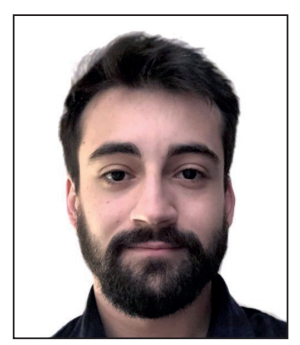
Martín Vaz-Álvarez https://orcid.org/0000-0002-4848-9795

Universidade de Santiago de Compostela, Facultade de Ciencias da Comunicación, Depto. de Ciencias da Comunicación Av. Castelao, s/n. Campus Norte 15782 Santiago de Compostela, Spain martin.vaz.alvarez@usc.es

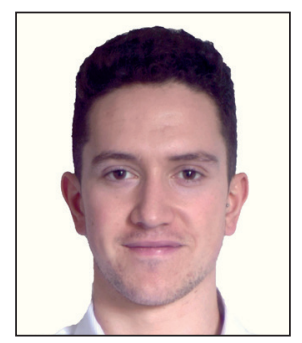

\author{
César Fieiras-Ceide \\ Grupo Novos Medios \\ Ronda de la Muralla, 142 \\ 27004 Lugo, España \\ cesar.fieiras@rai.usc.es
}

https://orcid.org/0000-0001-5606-3236

Universidade de Santiago de Compostela,

\begin{abstract}
This article analyses the response of European Public Service Media to the crisis caused by Covid-19, especially the impact of the pandemic on Europe's major public broadcasters, with a particular focus on technical and professional constraints, alterations in audience volume and habits, production strategies, type of broadcast content and journalists' routines. The research is based on public information from the European Broadcasting Union (EBU) and 19 in-depth, structured interviews with a convenience sample of innovation and strategy managers from public broadcasters in Austria $(O R F)$, Belgium (VRT and RTBF), Denmark (DR), Finland (YLE), France (France TV), Germany (ARD and ZDF), Great Britain $(B B C)$, Ireland (RTÉ), Italy (RAI), Netherlands (NPO), Portugal (RTP), Spain (RTVE), Sweden (SVT), Switzerland (RTS) and the European Broadcasting Union (EBU). The results indicate that the corporate projection of PSM was increased by emphasising their role as essential services and their defence of the values that characterise them. The pandemic forced the adaptation of programme production from technical standards to an emotional approach, accelerating a formal hybridisation with native online contents. Dependence on software grew and newsmaking processes were altered towards 'remote journalism'. Changes are drawn that may be maintained in the future.
\end{abstract}

\section{Funding}

This article is a result of the research project (RTI2018-096065-B-100) of the Spanish State Programme for $R+D+1$ aimed at the Challenges to Society of the Ministry of Science, Innovation and Universities (MCIU), State Research Agency (AEI) and the European Regional Development Fund (ERDF) on "New values, governance, financing and public audiovisual services for the Internet society: European and Spanish contrasts."

The author Martín Vaz-Álvarez is the beneficiary of an FPU contract (ref. FPU19/06204) granted by the Ministry of Science, Innovation and Universities of the Spanish Government. 


\section{Keywords}

Television; Public service media; PSM; Broadcasters; Chains; Audiences; Television programming; Production strategies; Covid-19; Pandemics; Coronavirus; Advertising; Platforms; News; Co-creation; Interactivity; Trends; Europe.

\section{Introduction}

The media have been considered an essential service to the population during the world crisis caused by Covid-19. Information on the evolution and impact of the pandemic has become a priority concern, together with the interest in broadcasting the norms, and the need to promote health education campaigns to change society's habits and align them with behaviours that can help avoid contagion. Entertainment content has also been essential at a time when business activity came to a halt, generating an increase in free time that confinement forced to occupy without leaving the house.

Habits have changed and audiovisual and online media consumption has increased, also due to the blockage of physical media (magazines and newspapers), while the ways of producing information and entertainment content have been transformed. This transformation is not exclusive to the media network, but it has caused a sudden change in the production dynamics, showing a path towards flexible organisations with improved processes because

"the crisis has highlighted the lack of more efficient structures and processes necessary in a digitalised society" (Cerezo, 2020, p. 10).

The Covid-19 crisis arises at a time when there is a consensus among researchers that the Public Service Media (PSM) have never been subject to so many political (Iosifidis, 2010), budgetary and technological pressures, as well as pressures for audience loss, innovation, editorial independence and change in public service values (Bonini, 2017) identified as: universality, independence, excellence, diversity, responsibility and innovation $(E B U, 2014)$. This debate also included the relevance of an exploration and analysis of the PSM strategic policies in terms of funding, governance and values, as highlighted by leading scholars in the field (Van-den-Bulck; Broughton Micova; Milosavljevic, 2018).

In this context of urgent and forced changes, it is especially pertinent to analyse the new conditions that the post-Covid-19 scenario has led to, especially with respect to its effects on audience habits, audience confidence in PSM and the technological, programmatic and strategic changes of these corporations, which are bound to reinforce actions in light of their public service commitment and to take decisions that not only aim to adapt to an exceptional situation, but also accelerate their transformation process towards the PSM of the future.

One of the variables that distinguishes the European PSM models is the role of the state in relation to the financing system of each of the corporations. After the economic crisis of 2007, many PSM experienced changes in their financing models (Radu, 2017), such as the German ARD, which, despite not being greatly affected by the crisis, replaced its licence fee with a more affordable payment per household. Furthermore, this crisis also brought about significant cuts that affected all corporations across the continent and have marked a trend that continues until today, with European PSM seeing their budgets reduced by an average of $4.3 \%$ over the last 4 years (EBU, 2019). Currently, the PSM of Denmark, the United Kingdom, Ireland, Sweden, Switzerland and Germany use the licence fee model as their main source of income, as opposed to the state funding approach present in Spain, Finland, Belgium and the Netherlands. In total, $77.7 \%$ of the budget of the PSM in the $E B U$ area comes from public funds $(E B U, 2019)$, which reinforces even more their responsibility in responding to crises that affect the public as a whole.

The pandemic has had an impact on the economic situation because competition between legacy media and on-demand services has increased, but above all because the Covid-19 has led to a standstill in business activity which is projected to reduce advertising revenue in the private media and in those with mixed funding. For the public media, this comes in a period when efforts to adjust economic balances have been usual. As Howcroft (2020) points out, the European PSM are facing a situation of uncertainty, aggravated by the economic crisis resulting from the pandemic and are preparing for a drop in advertising revenue due to investment cutbacks in actions and marketing Clarke (2020). This decline will be mitigated in part by an increase in subscribers for over-the-top (OTT) services, but all platforms will be affected. The impact is extended to the entire audiovisual sector because the impact radiates to the entire business environment linked to television productions.

The slowdown in the activity of the audiovisual sector was partly balanced by the incorporation of domestic scenarios into the television reality, both for the participation of journalists and experts invited to programmes, which aimed to stimulate audience participation. The domestic living room was turned into an improvised set, broadcast quality standards were reduced to help avoid network collapses, and the audience was incorporated
The domestic living room was turned into an improvised TV set, broadcast quality standards were lowered to help avoid network collapse and the audience was brought in as a co-creator of content 
as co-creators of content, in line with the contributions of authors such as Hutchinson (2017) or Vanhaeght and Donders (2015), who defined co-creation in the PSM as a mechanism for innovation in the media and audience participation, based on the transformation of the spectator into a produser (producer user) (Bruns, 2008).

Co-creation projects, insofar as they involve the audience in a shared narrative process, have the potential to promote different public service values such as representation, participation, innovation and diversity of content, whether through collaborations with other corporations or with the audience itself as users or professionals (Vaz-Álvarez; Túñez-López; Frazão-Nogueira, 2020). These public service values, in a context of social isolation, are particularly relevant in support of the three reiterated fundamentals of informing, entertaining, and educating.

Social confinement and the paralysis of commercial and business activities have led to an extraordinary situation that has not only abruptly burst, but has also disrupted the way in which people communicate socially, with sudden and spectacular increases in media consumption throughout the world, mainly in traditional and online television on pay-perview platforms. In Europe, the reach of public media evening news doubled during the peak days of the Covid-19 crisis and evening news increased its audience by an average of 14\% (Cimino et al., 2020a). The increase is even greater (20\%) among young audiences, although it grew in all demographic segments. In the United States, according to Nielsen, the increase in television consumption during the first weeks of the outbreak is estimated to be of around $60 \%$, television evening news increased its audience by $42 \%$ over the same period last year and cable news audiences increased by $92 \%$ compared to the first months of 2020 (Casero, 2020, p. 6).

Television news channels have been the most widely used source of Covid-19 information worldwide, and generally the second most reliable source behind government updates. Official government information is perceived as the most reliable source in Spain, the UK and France, while Germans and Italians rely more on TV news bulletins (Speck, 2020). Social networks present the biggest trust gap: while $47 \%$ use them, only $14 \%$ classify them among the most reliable sources. In contrast, fewer citizens turn to radio channels for news about the pandemic, but the confidence indicators in this medium remain the same (Speck, 2020).

This increase in audience is interpreted by PSM as a social response to the credibility of their information, which reinforce confidence in public service. According to Liz Corbin, Director of Information at the $E B U$,

"in times of national or international crisis, millions of people turn to public service media, on television, radio and online. When it comes to public health, the public wants a reliable source of information [...] And the coronavirus epidemic shows that journalists from these organizations go above and beyond to get the best news as quickly as possible.

https://www.meta-media.fr/2020/03/10/covid19-cooperation-inedite-des-redactions-de-laudiovisuel-publiceuropeen-et-canadien.html

In its April report, the EBU noted that PSM continue to increase news and information hours, and confirmed that visits/ sessions in public media and news applications doubled, web traffic increased significantly with

"a peak on 15 March with over 34.5 million unique visitors for news content" and also on PSM news channels on YouTube (Cimino; Besson, 2020, p. 17).

No studies have been found on the impact of media coverage in Europe on the levels of public knowledge about the pandemic. The Pew Research Center has assessed Americans' level of knowledge about the virus by differentiating responses among audiences that identify Fox News, MSNBC or CNN as their primary source of political news. The variations are significant: for example, $37 \%$ of Fox viewers interviewed believe that the virus comes from nature compared with $52 \%$ of those watching CNN and 66\% of those following MSNBC (Jutkowitz; Michel, 2020). 


\section{Methodology}

This article reviews the impact of the Covid-19 pandemic on Public Service Media in Europe, especially on television. It sets out to analyse, firstly, the initiatives of PSM in the face of the crisis, and then to identify how it has affected the main public television channels, bearing in mind that, while research agendas emphasise updating public value in order to recover legitimacy in the face of changes in social use or audience behaviour (Blaug; Horner; Lekhi, 2006; Arriaza; Nowak; Kuhn, 2015; Brink-Lunk; Ferrel-Lowe, 2016), research on regulation and governance are based more on the rhetoric of innovation and the impact of technological transformations (Freedman, 2016).

No specific research results have been identified that directly focus on the impact of Covid-19 on public service media, beyond the specific contributions of the European Broadcasting Union (EBU) and the contributions of individual media on their websites. The context analysis is therefore based on in-depth analysis of reports, documents, publications and videos of $E B U$ activities, which have developed an intense training and dissemination activity in the period from March to June 2020. It is considered a reliable reference point, comprising 70 members representing 116 organisations in 56 countries of the European Broadcasting Area, as defined by the International Telecommunications Union, or members of the Council of Europe. This literature review aims to identify what actions have corporations taken to protect public service values and to review the adjustments in programming and content production resulting from the situation of social confinement and business paralysis, with particular attention to the impact on technological processes and the recommendations on special measures to protect disadvantaged groups.

Having established this context for the reaction of PSM to the Covid-19 crisis, the research is aimed at understanding the impact of these changes on public television in Europe with an intentional sample in which the heads of various departments closely linked to content management are represented: innovation, strategy and artificial intelligence (AI) of the public televisions of Austria (ORF), Belgium (VRT and RTBF), Denmark (DR), Finland (YLE), France (France TV), Germany $(A R D$ and $Z D F)$, Great Britain $(B B C)$, Ireland $(R T E)$ ), Italy $(R A l)$, Netherlands $(N P O)$, Portugal $(R T P)$, Spain $(R T V E)$, Sweden $(S V T)$, Switzerland (RTS) and of $E B U$. The opinion of the managers of public corporations is sought to determine how it has affected the production of content and quality standards, the hybridisation of supports, the alteration of the routines of production of informative content and the formulas of participation of the audience as a generator of content.

The research is therefore proposed in an exploratory, descriptive manner with blind hypotheses. The documentary and web page review spans from March to June 2020. It is complemented by in-depth interviews with a structured questionnaire, with a specific section focused on the impact of Covid-19, without prior reveal of questions, through the Skype platform, from April 14 to May 31, 2020. It was considered that, due to the blind exploratory nature and the wide scope of the changes that had been brought about, a heterogeneous sample was not advisable due to the diversity of the organisational charts of the public corporations consulted. It was decided to establish a sample made up of heads of departments linked to areas affected by the crisis or interested in post-Covid-19 projections. Twenty-nine contacts were made and a convenience sample of 19 interviewees was finally validated in which the main PSM in Europe and the three media models described by Hallin and Mancini (2004) are represented, as detailed in table 1. The sample consisted of:

(JA/BBC) Jatin Aythora, Chief Architect responsible for Artificial Intelligence (AI).

(KB/France TV) Kati Bremme, IA Vision Director.

(DC/RTVE) David Corral, Head of Content Innovation.

$(A J / E B U)$ Atte Jääskeläinen, Professor at the LUT University and advisor at the EBU.

(LG/EBU) Lalya Gaye, Coordinator of Al and data initiatives.

(LV/RTBF) Loïc de Visscher, Director of Innovation.

(JL/SVT) Johan Linden, Director of Strategy.

(RA/ZDF) Robert Amlung, Director of Digital Strategy.

(AM/RAl) Alberto Messina, R\&D Area Manager.

(LB/RTS/EBU) Léonard Bouchet, Data and File Leader at RTS; Co-Director of IA.

(RW/RTÉ) Richard Waghorn, Director of Operations, Technology and Transformation.

(JF/DR) Jakob Faarvang, Digital Product Manager.

(JF/RTP) José Fragoso, Content Director of the main and international channel.

(BV/NPO/EBU) Bob van de Velde, Head of Data and Archives at RTS; Co-director of IA.

(EV/NPO) Egon Verharen, Innovation Leader.

(KP/ORF) Karl Petermichl, Head of Governance, Strategy and Innovation.

(SG/VRT) Sarah Geeroms, VRT Innovation Department

(JB/BR/ARD) Jonas Bedford-Strohm, Innovation Leader at Bayerischer Rundfunk.

(JK/YLE) Jarno Koponen, Head of IA and customisation. 
Table 1. Fitting of the intentional sample in the models by Hallin and Mancini (2004)

\begin{tabular}{|c|c|c|c|}
\hline Polarized pluralist & Democratic corporatist & Liberal & Others \\
\hline $\begin{array}{l}\text { France TV (France) } \\
\text { RAI (Italy) } \\
\text { RTP (Portugal) } \\
\text { RTVE (Spain) }\end{array}$ & $\begin{array}{l}\text { ARD (Germany) } \\
\text { DR (Denmark) } \\
\text { NPO (Netherlands) } \\
\text { ORF (Austria) } \\
\text { RTBF (Belgium) } \\
R T S \text { (Switzerland) } \\
\text { VRT (Belgium) } \\
\text { YLE (Finland) } \\
\text { ZDF (Germany) }\end{array}$ & $\begin{array}{l}B B C \text { (Great Britain) } \\
R T E ́ \text { (Ireland) }\end{array}$ & $\begin{array}{l}\text { European Broadcasting Union } \\
(E B U)\end{array}$ \\
\hline
\end{tabular}

\section{The impact of Covid-19 on PSM: reinforcing values and corporate/technological transformation}

The changes brought about by Covid-19 in the European PSM go beyond one-off adjustments because, as a whole, they are part of a corporate transformation in an increasingly digital environment in which, in the words of the President of the $E B U$, Noel Curran,

"more agile, risk-tolerant and experimental" means are needed because "it is not just a question of technology" but "they could be developing data and artificial intelligence capabilities; expanding multimedia production or reviewing the online offering itself" (Curran, 2020).

The EBU's review of reports and publications shows that the Covid-19 crisis has acted as an accelerator for the PSM digital transformation plans promoted through the Digital Transformation Initiative (DTI) launched in 2017 as an initiative to provide knowledge, tools and expertise to the media through advice and training. In the transformation scenario, the adjustments derived from the Covid-19 crisis were interpreted as "an intensive course" (De-Tender, 2020) and a change of pace since

"in this new reality, the imperative of digital transformation has gone from being important to being absolutely critical" (De-Tender et al., p. 7).

The changes resulting from the coronavirus crisis drove the offer transformation and also the digital capabilities of the PSM in an attempt to meet and satisfy the needs of the audience, but they have also been seen as

"a valuable opportunity to expand development teams, data and artificial intelligence capabilities, process automation, multimedia production and online offer. These changes will continue once the crisis is over, which can only be beneficial in the long term" (De-Tender et al., p. 7).

The adjustments of the PSM to the needs arising from social confinement were carried out in three phases:

"The first stage of the crisis is reactive, the second stage is managerial and the third stage is returning to normal, whatever that may be" (De-Tender et al., p. 7).

The urgency in reacting to the pandemic forced a focus on the actions needed to address the new social reality and public demands. Audience support is the positive side. On the opposite side is the economic balance in the adjustments forced to face unbudgeted expenses. The crisis is still happening and it is time to
Audience support is the positive side. On the opposite side is the economic balance, as unexpected adjustments forced unbudgeted expenses

"maximize the positive gains from the situation and mitigate the impact of defensive decision-making", as the authors of Casebook, a report which analyses 18 reference cases of good practices for the digital transformation of the PSM, state (Table 2).

It is still too early to detail the extent of the Covid-19 crisis in the digital transformation of the PSM, but the task has begun. The report derived from the analysis carried out at the end of May in a joint session of 17 organisations in the $E B U$ highlights the need to review

"the key issues identified that will help Members plan for a post-Covid-19 reality" (Scott, 2020, p. 2).

It is not possible to speak of a unanimous position, but at the same time as a possible budgetary adjustment is expected in the coming years due to the post-covid economic crisis, strategic lines of action are being drawn up based on priority actions in work organisation, organisational culture and digital transformation, which are summarised in Table 3.

Digital transformation requires a holistic approach across all dynamics and domains of each medium, one that places the public at the centre of the process, anchors decisions in data analysis and involves all links in the corporation's organigram with upward and downward synergies that reflect a strong digital culture built on strong leadership and a committed workforce, as concluded in the report (Scott, 2020). 
Table 2. Highlighted initiatives in the digital transformation of the European PSM. Source: EBU (2020c).

\begin{tabular}{|c|c|c|}
\hline PSM & Case name & Description \\
\hline RTBF & It all starts with the audience & $\begin{array}{l}\text { The audience, the centre of structures and processes. Two new departments to } \\
\text { analyse needs and suggest products. }\end{array}$ \\
\hline RTÉ & A new approach for a changing audience & $\begin{array}{l}\text { It aims to bring audiences to the heart of decision making and to create new seg- } \\
\text { ments of it through dialogue with the spectators. }\end{array}$ \\
\hline RAI & A future-proof remit & $\begin{array}{l}\text { They carry out a digital and multimedia transformation focused on the audience in } \\
\text { all their production. }\end{array}$ \\
\hline RTP & Amplifying the reach of live performing arts & $\begin{array}{l}\text { Cultural content to a wider audience with a digital platform dedicated to the perfor- } \\
\text { ming arts. }\end{array}$ \\
\hline SVT & Building relationships for mutual benefit & $\begin{array}{l}\text { The user accesses SVT Play with a button with his or her logo embedded in the } \\
\text { Swedish Com Hem cable operator's control. }\end{array}$ \\
\hline$B R$ & $\begin{array}{l}\text { Cultural partnerships enabling digital } \\
\text { innovation }\end{array}$ & $\begin{array}{l}\text { Museums and archives collaborate. As if they came from Kurt Eisner, the public } \\
\text { received multimedia messages, } 100 \text { years later. }\end{array}$ \\
\hline NPO & Personalisation with PSM values & $\begin{array}{l}\text { Their VOD platform recommends public service content. Combines audience panel } \\
\text { survey data with algorithms }\end{array}$ \\
\hline$B B C$ & $\begin{array}{l}\text { Leveraging content metadata to reach } \\
\text { underserved audiences }\end{array}$ & $\begin{array}{l}\text { They are working on standardizing content metadata to support creators in rea- } \\
\text { ching underserved audiences. }\end{array}$ \\
\hline$A R D$ & New building and tools for Tagesschau & $\begin{array}{l}\text { The news team changes buildings and creates a motivating management tool: 'one } \\
\text { house, one team, one brand'. }\end{array}$ \\
\hline ORF & $\begin{array}{l}\text { IP based newsgathering delivering wider } \\
\text { transformation }\end{array}$ & $\begin{array}{l}\text { Multimedia news gathering vehicles with IP technology to allow radio, video and } \\
\text { online in any circumstance. }\end{array}$ \\
\hline $\begin{array}{l}\text { Radio } \\
\text { France }\end{array}$ & Fostering innovation with an open API & $\begin{array}{l}\text { The audience and external agents have the capacity to develop innovative products } \\
\text { through Radio France's metadata. }\end{array}$ \\
\hline VRT & Innovating across the full spectrum & $\begin{array}{l}\text { They channel initiatives with: VRT Innovatie, dedicated to technology; VRT Sandbox, } \\
\text { to the market; and VRT Start-up, to consumers. }\end{array}$ \\
\hline $\begin{array}{l}\text { Sveriges } \\
\text { Radio }\end{array}$ & Engaged and informed leadership & $\begin{array}{l}\text { Management system that prioritizes involvement and strategic discussions in mana- } \\
\text { gement meetings. }\end{array}$ \\
\hline RÚV & Digital vision and strategy & $\begin{array}{l}\text { A renewed vision of their corporate strategy that prioritizes 'inspiring, connecting } \\
\text { and empowering' Icelanders. }\end{array}$ \\
\hline YLE & Building a digital culture on a daily basis & $\begin{array}{l}\text { The Agile Cultural Accelerator is a management method that facilitates the exchange } \\
\text { of knowledge and collaboration between staff. }\end{array}$ \\
\hline RTS & A radically different way of working & $\begin{array}{l}\text { An organisational framework that enables change and focuses on building trust, } \\
\text { distributing authority and generating innovation. }\end{array}$ \\
\hline FranceTV & A critical workforce agreement & $\begin{array}{l}\text { FranceTV decided to agree with all its staff on a plan for updating skills with a view } \\
\text { to the future. }\end{array}$ \\
\hline NRK & Redefining how we understand digital skills & $\begin{array}{l}\text { A trans-organisational network that allows employees to exchange ideas and learn } \\
\text { from each other. }\end{array}$ \\
\hline
\end{tabular}

Digital adjustment is one of the concerns in the referenced corporate transformation, together with the values of public service and the social perception of public service. Especially in the current context, and under an exceptional situation such as Covid-19 in which the public media play a critical role, it is a fundamental task to maintain and ensure the independence of these public corporations, since independence is the most important intrinsic value for the reputation, credibility, trust and legitimacy of the PSM (Karppinen; Moe, 2016).

Covid-19 has driven changes that go beyond temporary responses to urgent needs. As De-Tender et al. (2020, p. 7) state, "it is difficult to imagine that a corporate strategy will remain the same at the end of 2020 as it was at the beginning."

The transformation is accelerating at the same time as actions to consolidate the six reference values of the PSM, especially independence, are being reaffirmed. As a group, the PSM made an express request in March to governments and relevant authorities to guarantee the continuity of their activity in conditions that maintain their core values of

- independence,

- universality,

- diversity,

- responsibility,

- innovation, and

- excellence.
In an exceptional situation like Covid-19, where public media play a critical role, it is a fundamental task to maintain and ensure their independence as the most important intrinsic value for the reputation, credibility, trust and legitimacy of PSM 
Table 3. Post-Covid-19 strategic lines of action in the European PSM. Source: Scott (2020).

\begin{tabular}{|c|c|c|}
\hline Impact on & Trend & Effects \\
\hline \multirow{4}{*}{ Priorities } & \multirow{4}{*}{$\begin{array}{l}\text { The Covid-19 crisis has } \\
\text { changed the priorities and the } \\
\text { urgency of the digital transfor- } \\
\text { mation. }\end{array}$} & The new lines are not yet defined. \\
\hline & & Working from home has been a central focus, but it is not the whole picture. \\
\hline & & $\begin{array}{l}\text { Adaptation of the offer. Educational support platforms, but the acceptance has not always } \\
\text { been the desired one. }\end{array}$ \\
\hline & & The post-Covid economic crisis will affect the budget. \\
\hline \multirow{3}{*}{ Work } & \multirow{3}{*}{$\begin{array}{l}\text { The switch to remote working } \\
\text { was made at an extreme pace. } \\
\text { Hybrid models are expected to } \\
\text { remain. }\end{array}$} & Faster, more direct, more diverse and different communications. \\
\hline & & Agility. \\
\hline & & Many ideas, but few concrete decisions on the reshaping of work and organizations. \\
\hline \multirow{4}{*}{ Culture } & \multirow{4}{*}{$\begin{array}{l}\text { Covid-19 accelerates the digital } \\
\text { transformation and shows that } \\
\text { change is possible, although it } \\
\text { was done at a forced pace. }\end{array}$} & Good response to leadership during the crisis. \\
\hline & & Need to adjust equipment for a post-covid renewal period. \\
\hline & & New conditions exist that require new approaches and more useful tools (zoom-fatigue). \\
\hline & & Internal culture and external culture. \\
\hline \multirow{3}{*}{ Opportunities } & \multirow{3}{*}{$\begin{array}{l}\text { The PSM have never been as } \\
\text { open to change as they are } \\
\text { now. }\end{array}$} & Finance will soon be the key driver of change. \\
\hline & & Along with the obvious risk, the crisis offers a unique opportunity. \\
\hline & & Need to adjust speed. \\
\hline
\end{tabular}

Through the $E B U$, they endorsed the joint statement by the United Nations monitors of freedom of expression and freedom of the media, the Inter-American Commission on Human Rights and the Representative on Freedom of the Media of the Organization for Security and Cooperation in Europe calling on governments to promote and protect access to and free flow of information during the pandemic.

https://www.ohchr.org/EN/NewsEvents/Pages/DisplayNews.aspx?News/D=25729\&LangID=E

They also endorsed the EU declaration on emergency measures by member states, which states that respect for freedom of expression and legal certainty are essential in these uncertain times and recognises the importance of free and independent media for democracy.

https://ec.europa.eu/commission/presscorner/detail/en/statement_20_567

At the same time, other initiatives are being developed to reinforce the values of public service as the protection of diversity through the document in which 24 organizations from 16 European countries and Canada have reflected the actions developed on issues of gender equality and social inclusion, and have provided recommendations for the coverage of the impact of Covid-19 with a close attention to informing on violence against women, the distribution of domestic workload or references to citizens of particularly affected countries that could stigmatize them. The need for attention to linguistic plurality and gender balance in the selection of experts to be given voice by the media is also mentioned, as detailed in Table 4.

Something similar occurs with the reinforcement of Public Service Media as educational support to mitigate the impact of school closures by adjusting their programming and incorporating specific activities in collaboration with the Ministry of Education of each country. In addition, based on the experience of each territory, virtual workshops on educational transmission were developed as a way of participating, through the $E B U$, in the Unesco initiative to promote learning material to children and young people in areas of greater risk. A manual of best practices for child-oriented content was also produced, which the $E B U$ keeps in restricted access to its members (EBU, 2020a).

There are many examples. FranceTV launched a series of live educational programmes under the Lumni brand, presented by real teachers, and a new programme called Allo Okoo, which responded to messages from young people about the coronavirus in an age-appropriate manner. The Norwegian NRK saw how children's audiences started to use platforms that they did not typically go to, such as linear TV or desktop, and decided to diversify their content through these platforms to reach as many children as possible. $R A I$, for its part, decided to ask sports figures and others to send videos aimed at children to motivate them to play sport. They soon realised that there was a great demand for interaction in the children's sector and these messages were extended to personal stories or drawings ( $E B U$,

The concern for the perception of public service by the media is evident in the actions of the PSM to emphasise it as an essential service to society

2020a). 
Table 4. Recommendations to PSM to promote gender equality and diversity in information on Covid-19. Source: $E B U$ (2020d).

\begin{tabular}{|c|c|c|}
\hline Scope & Combat & Recommendations to the PSM \\
\hline \multirow{7}{*}{ Gender equality } & \multirow{3}{*}{ Increase in violence } & Working in partnership with governments and associations that focus on violence against women. \\
\hline & & Help inform potentially violent men how to get help before they act. \\
\hline & & Develop a narrative that invites everyone to take action and warn if a potential danger is detected. \\
\hline & \multirow{2}{*}{$\begin{array}{l}\text { Increased workload for } \\
\text { women }\end{array}$} & Avoiding framing home chores as belonging to women. \\
\hline & & To serve PSM employees (45\% in Europe are women). \\
\hline & \multirow{2}{*}{$\begin{array}{l}\text { Gender imbalance } \\
\text { in the selection of } \\
\text { experts given voice by } \\
\text { the media to report on } \\
\text { Covid-19 }\end{array}$} & $\begin{array}{l}\text { Projects such as the } B B C 50: 50 \text { Challenge are proving effective in increasing women's represen- } \\
\text { tation and participation and maintaining a high level of awareness within editorial teams. }\end{array}$ \\
\hline & & $\begin{array}{l}\text { Overcome the difficulties in sharing lists due to each country's data protection legislation and } \\
\text { promote institutional lists such as the Brussels Binder } 10 \text { or those drawn up by professional or } \\
\text { women's organisations, such as the Women in Global Health expert list. }\end{array}$ \\
\hline \multirow{6}{*}{ Diversity } & \multirow{4}{*}{$\begin{array}{l}\text { Covid-19's coverage } \\
\text { and information rea- } \\
\text { ches everyone and also } \\
\text { represents the most } \\
\text { disadvantaged }\end{array}$} & Taking into account the accessibility for people with visual and hearing disabilities \\
\hline & & Capturing all realities and incorporating as voices citizens of all origins and social classes. \\
\hline & & $\begin{array}{l}\text { Attending to minority languages, whether in live broadcasts, on their websites or through } \\
\text { social platforms. }\end{array}$ \\
\hline & & Taking into account migrants and countering the misinformation promoted by human traffickers. \\
\hline & \multirow{2}{*}{$\begin{array}{l}\text { Prevention of xe- } \\
\text { nophobia }\end{array}$} & $\begin{array}{l}\text { Newsrooms should cultivate a taste for inclusive language and avoid framing information in a } \\
\text { way that stigmatizes specific communities. }\end{array}$ \\
\hline & & $\begin{array}{l}\text { PSM can proactively develop inclusive narratives that dismantle the stigma of specific commu- } \\
\text { nities as disseminators of the virus. }\end{array}$ \\
\hline \multicolumn{3}{|c|}{ 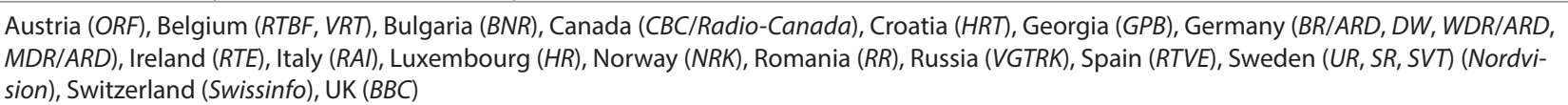 } \\
\hline
\end{tabular}

The concern for the perception of public service by the audience is evident in the actions to emphasise the message of the PSM as an essential service to society with campaigns on the role developed during the Covid-19 crisis. One of the first initiatives has been the $B B C$ campaign with 60 and 90 second videos in which it illustrates with real images the poem Don't quit, by Edgar Guest, portraying the effects of the pandemic through a song of resilience and overcoming of adverse situations, read by well-known actors. The initiative promotes a motivational message and an emotionally-oriented message of belonging ("together, we'll get through") which the BBC defines as one of the actions that help

"create shared experiences and emotions that will bring us together as a society when we need it most."

https://www.bbc.co.uk/mediacentre/latestnews/2020/coronavirus-film

This interest in building a positive image has been transversal to television advertising, which was redirected to promote more the brand image than the products with motivational and belonging content focused on positive group concepts projected into the future: solidarity, collaboration, commitment, hope for when the confinement is over. The media increased their corporate communication along the same lines, but with a nuance between the public ones, more defined to messages of social health education and normative dissemination, and the private ones, more oriented to motivational contents and social awareness. This orientation could allow an audience analysis of each country as a community and could be interpreted in terms of internal communication management because it assumes the four main functions that Robbins and Judge (2009, pp. 351-352) identify with control, motivation, emotional expression and information, which, in this case, could be transferred to normative, motivational, belonging and informative content, respectively, which are identified with the media during the coronavirus crisis.

The Internet has not been immune to the increase in usage figures either. Online traffic in television websites would draw a similar timeline to that of television audiences for conventional broadcasts: spectacular increases when confinement is declared, but with a constantly decreasing evolution. The websites are reinforced with service information and interactive applications that complement the current information and offer additional services. RTVE has added a verifier for news on social networks, which are sent to them by the audience through WhatsApp. The BBC, for example, has created a rapid response unit working with social media companies to eliminate fake news and harmful content such as false experts broadcasting false medical information.

On the television scene, the increase in online traffic from RTVE is the highest, in percentual terms, of the PSM websites in Europe when comparing the total number of visitors offered by Similarweb (2020). Although there is a downward trend in all of them, they remain above the total number of visitors in February, except for RAI. The presence and activity 
in traditional and emerging social networks are also increasing across the continent. The $E B U$ included in its training activities programme on Covid-19, seminars on the management of communities on Facebook and keys to attracting attention on Tik Tok, encouraged by its impact on young audiences and its use by the WHO as a broadcasting platform with high levels of virality. Events such as the Eurovision Song Contest semi-finals were also exported to YouTube and the final event was replaced by a recorded programme made through home connections with the participants; Eurovision: Europe shine a light, which reached 73 million viewers on free TV, in addition to 53 million unique viewers on YouTube.

The global traffic figures only indicate a trend and would in themselves deserve a detailed investigation, as they $\mathrm{x}$-ray the behaviour of citizens in online environments promoted by PSM in a situation of hyperactivity on the net, which could be linked to the challenge launched in mid-2018 by the $B B C$ to evolve from the strategic concept of the PSM to that of Public Service Internet (PSI), that is, to make the British public audiovisual service the trusted global content provider for the network ( $B B C R \& D, 2018$; Fuchs, 2018).

Table 5. Evolution of traffic on the websites of European PSM. Source: Similarweb.

\begin{tabular}{|c|c|c|c|c|c|c|c|c|}
\hline \multirow{2}{*}{ PSM web } & \multirow{2}{*}{$\begin{array}{c}\text { February } \\
\text { Total visits* }\end{array}$} & \multicolumn{2}{|c|}{ March } & \multicolumn{2}{|c|}{ April } & \multicolumn{2}{|c|}{ May } & \multirow{2}{*}{$\begin{array}{l}12 / 19-05 / 20 \\
\text { Bounce rate } \%\end{array}$} \\
\hline & & Total visits* & Evolution \% & Total visits* & Evolution \% & Total visits* & Evolution \% & \\
\hline Ard.de & 14,5 & 21,7 & 149,66 & 18,5 & $-14,75$ & 15,8 & $-14,59$ & 59,13 \\
\hline Bbc.co.uk & 542,0 & 698,5 & 128,87 & 623,5 & $-10,74$ & 604,0 & $-3,13$ & 47,61 \\
\hline Bbc.com & 427,0 & 606,0 & 141,92 & 524,5 & $-13,45$ & 451,5 & $-13,92$ & 65,22 \\
\hline France.tv & 16,0 & 20,8 & 130,00 & 19,4 & $-6,73$ & 16,2 & $-16,49$ & 42,82 \\
\hline Orf.at & 48,0 & 78,6 & 163,75 & 66,3 & $-15,65$ & 59,4 & $-10,41$ & 38,64 \\
\hline Rai.it & 7,55 & 10,4 & 137,75 & 8,75 & $-15,87$ & 7,1 & $-18,86$ & 58,44 \\
\hline Rtbf.be & 16,2 & 28,0 & 172,84 & 26,7 & $-4,64$ & 21,4 & $-19,85$ & 61,63 \\
\hline Rtve.es & 28,7 & 65,3 & 227,53 & 52,0 & $-20,37$ & 45,3 & $-12,88$ & 54,37 \\
\hline Yle.fi & 49,0 & 69,5 & 141,84 & 62,3 & $-10,36$ & 57,3 & $-8,03$ & 47,37 \\
\hline Zdf.de & 39,3 & 47,5 & 120,87 & 41,3 & $-13,05$ & 40,8 & $-1,21$ & 49,33 \\
\hline
\end{tabular}

* million

European public radio has also experienced one of its best moments in times of crisis. It supported citizens during Covid-19 by giving voice to their experiences, providing proven information and entertainment, encouraging people to stay at home, supporting a sense of community (Fernández-Quijada; Speck, 2020). There was an increase in information services, especially those related to the pandemic. NDR was a great success with its podcasts, as was ORF's first radio channel, with a programme that responded to listeners' concerns. The radios pulled out files to increase their offer of reports and music and even helped to give a certain degree of freedom during the confinement. RAI Radio 2 allowed its listeners to celebrate special occasions on air and live on social networks: birthdays, graduations and even weddings.

Radio consumption habits were modified by the confinement (Fernández-Quijada; Speck, 2020): Fewer people listened to it, but listeners stayed engaged longer, mainly focused on the news. People who worked at home used their digital devices more to listen to the radio, which did not compensate for the drop in consumption on car trips. Audience numbers for music programmes also suffered. The proportion of listeners increased by $15 \%$ among young people and $26 \%$ among young adults in March 2020 compared to the first quarter of 2019. Public radio reached its peak in mid-March, when the situation was most critical.

\section{The experts' opinion}

The return of television programming to the 'new normality' will mark a different way of approaching the production of both informative and entertainment content, adjustments in the way news are covered and produced, changes in production models with new ways of seeking profitability at a lower cost, a readjustment in technical standards, and also new ways of relating to the audience.

The experts predict that

"we will foreseeably see an evolution towards networked organisational models, made up of core structures that will be coordinated with other organisations fed by specialised journalists, sector experts, scientists, technicians, etc. and where the product manager will be consolidated as the person responsible for digital products and a sort of agent of change" (Cerezo, 2020, p. 10).

They are also inclined to anticipate permanent changes derived from the advance of

"the applications for data search and management, dynamic visualisation of information and artificial intelligence have formed part of the 'high technology' package used by the digital media to improve information coverage of the consequences of Covid-19 for society" (Costa-Sánchez; López-García, 2020, p. 9). 
These premises underpin the structured questionnaire of in-depth interviews conducted with 19 senior managers of public television stations in Austria (ORF), Belgium (VRT and RTBF), Denmark (DR), Finland (YLE), France (France TV), Germany $(A R D$ and $Z D F)$, Great Britain $(B B C)$, Holland (NPO), Ireland (RTÉ), Italy $(R A l)$, Portugal $(R T P)$, Spain $(R T V E)$, Sweden (SVT), Switzerland (RTS), and the $E B U$ to summarise how the coronavirus crisis has affected the audiovisual media and whether these have been one-off impacts or the start of adjustments that will define a new way of doing television in the future, especially in terms of value and production strategies, technical quality standards, hybridisation of media, novel forms of newsmaking and participatory and interactive content.

\subsection{Softwarization of the production}

Covid-19 has directly affected program production by limiting or even preventing access to the television studios and causing a forced adaptation of the formats through creative formulas, as it has happened in some $B B C$ news services, which were presented from the anchorman's living room, for example. In addition to these adaptations, there are cases of contents that have already been designed in this context of limited production capacity and which, due to their success, may suggest a paradigm change in what we understand as the value of technical production.

On the financial side, European public broadcasters have suffered significant cuts in their budget. Even so, they stress the point that, however, they have been less affected than private media, who directly depend on the income they receive from advertising. Furthermore, this unexpected situation has served to strengthen the position of the PSM and the relationship with their audience, which the corporations see as an opportunity to maintain this newly formed connection.

"The coronavirus has had a huge impact on our budget, yet we have fared better than our private media competitors because they depend more on the revenue they receive from advertising" (KB/France TV).

"With Covid-19 we have come out stronger, the need has been identified for objective, pluralistic and reliable means in the midst of this information bombardment" (KP/ORF).

"The PSM have definitely strengthened their position towards the public during this crisis. We have become a key element in the fight against the virus. Now we need to use this experience and goodwill, together with a powerful storytelling, to maintain the new link created with the audiences" (KB/France TV).

The experts' point of view is that traditional television accelerated its approach to broadcasting products native to the online world and immediately adjusted their production mechanisms, as a matter of necessity, to technical formats and standards specific to web broadcasting. There is no clear prognosis as to whether this trend will continue once the period of limitations has passed, but they consider that the adaptation and designs of programmes during quarantine set a precedent that shows that it is possible to make successful content without the need to invest large amounts of money and that it is possible to replace, when necessary, the focus on the value of technical production with a focus on emotional and empathetic values.

"In general we are seeing content moving towards quick and easy formats, with a more behind-the-scenes style that no longer seeks the quality standards seen before. A good example is Jimmy Fallon's show, which despite being made from his living room gets millions and millions of viewers" (JB/ARD).

"Television is pure emotion and machines or technology don't give it to you. Content is the result of people's talent and their ability to convey emotion, that's what audiences want. With more powerful technological resources, we can create better scenarios and situations and achieve more efficient workflows, but in the content part we have an irreplaceable human component" (JF/RTP).

At the same time, they indicate that this situation has brought to light new forms of production more based on software and remote solutions, driving the implementation of these new utilities in the corporations. Changes in programming have also been transcendent, with significant increases in entertainment, educational and informational formats and even new programs to promote sports at home.

"In the time of the coronavirus everything has changed drastically. Many of the things we have prepared now find application, such as remote working and virtualisation. This can lead us to the next step which will be 5G, so that all these processes have stability, are synchronized and with good quality. Right now, as far as innovation is concerned, we have the technical section of digitalisation, Cloud and 5G, and on the other hand the administrative part and logistical support" (DC/VTN).

"If we had not developed our platform and evolved from our traditional systems, we would not have been able to react to this crisis, but in reality what the Covid-19 has done is that it has been the agent of change, it has forced people to change without any doubt" (RW/RTÉ).

"The remote production technology part will last and be used in the future as well. We will see more cloud-based production for most programmes. But, as soon as possible, we will bring in more guests and the audiences will come back to the TV programmes. We hope that some of the programmes will also be about other news besides Covid-19" (EV/NPO).

"We made important changes to the programming. We reinforced the daily news, educational programmes and the film offer with classics and premieres of French cinema. We have also expanded our entertainment content and offered formats for French people to do sport at home" (KB/France TV). 
The PSM integrated in the EBU have shared practices and experiences. The way in which the use of own resources is used in each country was socialised, such as the images and archive programmes, partnerships with cloud providers, or advices on the protection of corporate infrastructure. Other initiatives have also been launched to encourage such sharing, such as the dedicated online channel (Slack) which operates $24 / 7$ to share tips and news on technical issues. The News Exchange program has also encouraged an open information flow between corporations.

\subsection{Hybridisation of platforms}

Sports are one of the disciplines that most felt the effects of the Covid-19, as all sporting activities were cancelled. For public service media, and especially for those channels dedicated exclusively to sports, it has been a challenge that each corporation has tried to solve in a different way. The Hungarian MTVA's sports channel M4 decided to make use of the archive and chose to reproduce past sports events which held a special meaning by the Hungarians, such as their 3-0 victory over Brazil in a football match in 1986. The $B B C$, with the same commitment to nostalgia, chose to transform its famous Match of the Day into a programme they renamed Match of their Day in which different experts discussed the sporting events that had marked them most. YLE, on the other hand, decided to take a step back and iterate on the purpose they had set themselves as a public service in the broadcasting of sports: the creation of shared experiences for Finns. The decision was, from a broader perspective, to devote the efforts of sports editors to generating stories, reports, and interactive content about sports, in the absence of the events themselves (EBU, 2020b).

During the $E B U$ discussions on the effects of Covid-19, these 3 corporations agreed that they will need to be more prepared to put in place a plan B for sports coverage when needed, and pay attention to technological developments from which they can benefit in a similar future situation (EBU, 2020b).

The lack of sporting events during the confinement stage led to the growth of the only possible alternative to physical competition: virtual tournaments. During the confinement, e-sports increased their appearance on social networks. In the second half of March they experienced a $71 \%$ growth in conversation volume on Twitter and a $38 \%$ increase in unique visitors compared to the first two weeks of the month (Chadha, 2020). Online and offline environments have been hybridised, bringing gamification to television content and interaction through platforms such as Twitch and an accelerated insertion of e-sports in the media scene, with the capacity to function in both new and traditional media, to attract the attention of advertisers from different sectors (technology, sports, entertainment...) and to encourage co-creation between professionals and figures from culture, sport and communication. In this context, the new formats have an unexpected opportunity to make their way.

Experts agree that online environments and streaming services are the future channels of consumption. They point out that innovation will be essential to give continuity to the growth of their platforms, since in these digital spaces the formats and services offered must be constantly reinvented to remain relevant to their audience.

"The future is in online environments, new formats and platforms will appear. Innovation is fundamental here, as new ways of doing things are emerging every month. It is in the air to say that the decision-making process has become much faster and many programmers are trying to develop new formats based on the current difficult situation" (JL/SVT).

"The use of our VoD platform has been growing (+30\%) not only for people staying at home and watching more programmes, but also to catch up with the most important news and also with live TV (through our OTT service)" (BV/NPO/EBU).

"The first step for innovation is going to be to move completely away from traditional broadcasting to IP-based broadcasting, or IP-based streaming services" (JA/BBC).

Even so, as ZDF points out, before the arrival of the pandemic they were suffering significant losses in linear services that were not compensated for by Mediathek (online services). This decline is mainly in young audiences, so they consider it essential to renew services to attract their attention. Other corporations such as $R A$ l reinforce this idea, and although they are aware of the upward trend in online services, they maintain that traditional television will continue to be important in the coming years.

"The process of change is underway, as we all know. Linear television, with the exception of this particular moment, is losing out, especially to younger audiences. In the last two years in Germany the loss was quite significant in this service. And, unfortunately, Mediathek does not compensate for the losses. So, it doesn't really live up to the expectation, that it can really take on the same role as linear television" (RA/ZDF).

"The trend is an increase in the importance of online services, this is by default. But I am less sure of the fact that linear television is disappearing completely. I see that this medium is still very important, and I believe that it will continue to be so in the years to come" (AM/RAI).

\subsection{New routines in newsmaking: producing online for offline}

In the media in general and on television in particular, the reaction has been to redirect content to issues related to the pandemic. The $E B U$ 's March report already reflects that news coverage has been expanded, special slots have been 
scheduled at prime time and windows have been opened to broadcast official information, government statements and press conferences. It is worth noting that polyphony has been expanded to give prominence to experts.

"In many cases, information programming is open to audience participation, allowing citizens to address their most pressing problems and ask urgent questions during a period of uncertainty" (Cimino et al., 2020, p. 18).

The Covid-19 crisis has altered the productive routines of journalists, with the working from home situation and virtualisation as the main actors of change towards remote journalism. Information professionals have had to master remote production tools, adapt to new schedules and take on new responsibilities that were not part of their daily lives until the arrival of the pandemic. The coronavirus has acted as an agent of change, as it has forced the media to adopt measures that months ago seemed distant and even unfeasible.

"Covid-19 has been the agent of change, forcing corporations to change without question. It has forced us to embrace change, whether we like it or not" (RW/RTÉ).

"Something that was considered difficult, or almost impossible, such as remote work, is now a daily routine. Before it was almost unthinkable that this could happen, now it was set up in just one month and it works without problems" (AJ/EBU).

"We changed our schedule, because a lot of the event schedule has been cancelled and had to be filled with new schedules that could be produced remotely" (EV/NPO).

"Staff are expected to work for the news if necessary, and part of our team is now linked to the website. The sports department has no events to work with, so they are now covering news and current affairs" (JL/SVT).

In this context, journalists have tested and developed new formulas for generating content. In addition to the frequent remote connections with guests, they have sometimes introduced the audience to the creation process, as they ensure that their participation is more likely during this period. They have also established new communication channels with their audience in order to have a more direct and effective conversation. The communicators have learned to deal with social distancing and even identify proposals in which they try to maintain the pre-Covid-19 production systems by respecting the measures recommended by the health authorities.

"We have examples of co-creation with the coronavirus. We collect videos that we receive from people singing popular pieces from Denmark for later broadcast. Usually these initiatives do not work as well as they do now, it is difficult to generate user contributions" (JF/DR).

"In the corporations, applications were developed specifically for this situation, so that people can contact them directly and thus be treated more closely" (LG/EBU).

"We have been testing whether we can continue to produce our daily fiction programme taking into account the rules of social distancing. We will share these learnings with the industry when we get results" (SG/VRT).

The experts' view is that the impact of the coronavirus will leave its mark on news reports, which will have to include the lessons learned as well as structural and production improvements in order to keep them on their roadmaps. Travel and trips will be reduced due to the more than positive response offered by the videoconferencing systems, and the cloud will become a regular working space for journalists. Some of the corporations are evaluating extending the home office system beyond the coronavirus. In particular, France TV is considering keeping it a couple of days a week, while considering its structure based on lighter recording equipment. The pandemic will also encourage the introduction of new technologies, such as $5 \mathrm{G}$.

"I predict that there will be a tendency to reverse some of the things we have changed during this crisis, but I think we should not forget those that could improve our way of working from a structural point of view" (LB/ $R T S / E B U)$.

"The home office experiment went very well, it will surely persist after the coronavirus a couple of days a week. There will be more collaboration tools in the cloud and new formats and narratives, with lighter recording equipment" (KB/France TV).

"In coronavirus times everything has changed dramatically. This can lead us to the next step which will be 5G, so that the whole process will be stable, synchronised and with good quality" (DC/RTVE).

"One thing that will endure are the distant working methods that are being developed. In Sweden we do a lot of travelling that will be reduced" (JL/SVT).

"We will see more cloud-based production for most programmes, that makes our processes faster and easier" (EV/NPO).

The effects of the Covid-19 crisis on journalists vary according to their position and responsibilities. The interviewees make a distinction between what they call the old world and the new world. The former refers to traditional journalistic environments in which production systems are linked to field work or the physical presence of the reporter in the newsroom or studio. They are journalists who have greater difficulty in adapting to the new needs of the changes in television production, while the communicators of the new world, already accustomed to digitalisation and working in the cloud, have hardly suffered. 
"The working environment has changed for many people. The impact has been different, as we have both the old and the new world working at the same time in our corporation. For people in the 'new world' not much has changed, except that it is psychologically exhausting not to see each other every day" (BR/ARD).

"The people of the 'old world' are in trouble, because they can no longer be in the same way in the large production systems. In addition, some need to work within the old publishing systems that are not cloud-based, or not accessible through any device. They have never used these technologies and that has been very difficult to apply" (BR/ARD).

\subsection{Participatory content: co-creation and interactivity}

The coronavirus crisis has also fostered the values of participation in public service media in a situation where, according to the experts' opinion, the audience seems more inclined to interact. The changes in programming are not only visible in the fact that there are cancellations or readjustments to combine live online and on-set participation, but they also affect content. Pennington (2020) points out in his analysis on v-net.tv how the BBC or the NDR and RTL, in Germany, have broadcast "behind closed doors" spaces of political current affairs or have reoriented the issues they deal with to focus on matters related to the pandemic or physical activity, education, home or religion. Some European PSM such as RTBF are taking advantage of this situation to consolidate a participatory community in digital environments.

"We have a $24 / 7$ hotline that is online and where the audience can ask questions to SVT. We have not stopped at any time, journalists and experts are involved. It's a very interesting experience as we identify the questions people are asking, so we know what interests them" (JL/SVT).

"One of our television programmes, which is also one of the most watched in the history of the company, built up its content over the last few months through images sent in by the audience. People filmed their surroundings, some animals in their garden, and shared it with the production team. We are working on creating a stable and participatory community" (LV/RTBF).

The $B B C$ launched a campaign urging its audience to send in their "last normal picture." It got a massive response that transcended its geographical boundaries and ended up placing the hashtag \#LastNormalPhoto as the third global trend on Twitter. The Swedish SVT enabled 24/7 coverage of the coronavirus, with programs that answered audience questions about the virus. The most relevant questions are then adapted and answered using other formats.

The Danish $D R$ found an ally for participation through music with a domestic performance by music director Phillip Faber, with a broadcast on Facebook in which he invited the audience to submit their own recordings of Danish folk songs and classic films. From the next day, this format was transferred to $D R 1, D R$ 's main channel, and in just two weeks it had already reached 340,000 viewers (Rosenmeier, 2020). A second DR programme called Community Song, in which different national musicians come together to play and sing, attracted an audience of 1.2 million viewers, a fifth of the total Danish population.

\section{Conclusions}

Covid-19 has globally changed the way of making and consuming offline and online television. It is a globalised change. Regardless of the television or the country being analysed, the adjustments in broadcasts and the reactions of the audience are similar. Experts agree that there has been a move to creatively adjust needs and to keep products on air with the least impact on content quality, albeit with a significant drop in technical standards. They also share the impression that some adjustments in the production and elaboration of informative and entertainment content have been the beginning of changes that will provoke new ways of understanding television products and of facing their business models, although they also consider that it is still premature to venture which will survive.

During the global crisis caused by the Covid-19 the media have been an essential service to the population. Consumption has multiplied, especially on television in all its media (traditional, streaming or on demand) and in online environments, just at a time of concern about the future of audiences (Bonini, 2017) and with strong increases in segments of the population, such as young people, who had abandoned conventional television. The offer of content also increased, mainly informative, although due to the prolonged duration of the pandemic it is assumed that audience fatigue may have occurred due to the repeated and almost monothematic presence of the coronavirus on the agenda. In Europe, the scope of the public media's evening news doubled during the peak days of the Covid-19 crisis.

Changes in content are identified, with more weight given to corporate, motivational and/or messages that promote a sense of belonging, also in advertising. Consumer habits have changed in all media and platforms due to the increase in leisure time during the confinement, which has caused hyperactivity in free-to-air television audiences and in SVOD. As social de-confinement advances, the overall number of television viewers is decreasing.

The pandemic has had an impact on the economic situation of the media because of increased competition between traditional channels and on-demand services, but above all because Covid-19 has led to a reduction in advertising revenue on private channels and those with mixed funding, reaching the public channels in a period when efforts to adjust economic balances have been the norm. The impact is being felt by the entire audiovisual business sector linked to television productions. 
On the operational side, the pandemic has forced a different way of producing all types of content, both informative and entertainment, adjustments in the way news are covered and produced, changes in production models with new ways of seeking profitability at a lower cost, a reevaluation of technical standards, and also new ways of relating to the audience. There has been a hybridisation of online and offline production, with derivations in both directions that allow us to talk about, for example, collaborative synergies between traditional television and online event platforms, such as Twitch.

The coronavirus has acted as an accelerating agent of change and journalists have tested and developed new formulas for generating content, not only in frequent remote connections with guests but even incorporating the audience into the process of generating and creating content, establishing a more direct and effective conversation. It has been a new modality of what can be labeled as remote journalism, which now presents the opportunity to address their needs in infrastructure, services, tools and responsibilities to assess their momentum and permanence as an alternative way of producing audiovisual information.

The question now is to determine which of these changes have been one-off adaptations and which will become structural reforms that can change the way television is made or at least generate alternative modes. The diagnoses of the experts in innovation and content management of the main European PSM converge on at least three aspects:

- There is a renewed vision of public service on behalf of the audience, which means that increased participation and response to the proposals made by the PSM can open up a path that strengthens the relationship between public media and their viewers.

- The hybridisation of television formats towards the sensibilities and productions forms of the web can succeed in attracting younger audiences who consume content on online platforms. This will also depend on the ability of corporations to adapt formats and include cultural intermediaries that stand out in the online world.

- The different technical and technological needs that corporations have experienced during this crisis may encourage the interest of public television in generating innovation ecosystems through media accelerators, a trend that was already being perceived in the European PSM and which may provide solutions and new ideas to cover possible technological or content gaps in the future.

In any case, the changes caused by Covid-19 go beyond momentary readjustments. The pandemic has broken out at a time when technological change is beginning to emerge as a priority action in the future to achieve digital transformation and build a solid digital culture in corporations, but without renouncing the six core values of PSM (independence, universality, diversity, responsibility, innovation and excellence). The reinforcement of these values can also be seen in the context of corporate strategies to promote the identification of the PSM as a public service and to highlight their essential role and the need to promote the protection of diversity, equality and social inclusion. If the crisis has visibly transformed production processes in the media, it has also acted as a fuse to demand safeguarded access and free circulation of information, as regards freedom of expression and legal certainty, and to guarantee the independence of the PSM as a fundamental valuable service to citizens.

\section{References}

Arriaza-Ibarra, Karen; Nowak, Eva; Kuhn, Raymond (eds.) (2015). Public service media in Europe: a comparative approach. New York: Routledge. ISBN: 9781138020689

BBC (2020a). BBC launches new film to demonstrate its role as a public service broadcaster in a time of national crisis. British Broadcasting Corporation.

https://www.bbc.co.uk/mediacentre/latestnews/2020/coronavirus-film

BBC (2020b). Coronavirus: Fake news crackdown by UK government. BBC, 30 March. https://www.bbc.com/news/technology-52086284

BBC R\&D (2018). Building a public service Internet. What might a Internet that upholds public service values look like? https://www.bbc.co.uk/rd/projects/public-service-internet

Blaug, Ricardo; Horner, Louise; Lekhi, Rohit (2006). Public value, politics and public management. London: The Work Foundation. ISBN: 9781626162624

Bonini, Tiziano; Pais, Ivana (2017). "Hacking public service media funding: A scenario for rethinking the license fee as a form of civic crowdfunding". International journal on media management, v. 19, n. 2, pp. 123-143.

https://doi.org/10.1080/14241277.2017.1298109

Brink-Lund, Anker; Ferrell-Lowe, Gregory (2016). “Public service broadcasting”. In: Mazzoleni, G. (2016), The internacional encyclopedia of political communication. The Willey Blackwell-ICA.

https://doi.org/10.1002/9781118541555.wbiepc178 
Bruns, Axel (2008). Blogs, Wikipedia, Second Life, and beyond: from production to produsage. Peter Lang Publishing. ISBN: 9780820488677

Casero-Ripollés, Andreu (2020). "Impact of Covid-19 on the media system. Communicative and democratic consequences of news consumption during the outbreak". El profesional de la información, v. 29, n. 2, e290223.

https://doi.org/10.3145/epi.2020.mar.23

Cerezo, Pepe (2020). El impacto de la pandemia en la prensa.

http://evocaimagen.com/dosieres/dosier-evoca-09-medios-y-coronavirus.pdf

Chadha, Rishi (2020). From esports to game launches, here's why conversations around video games are surging on Twitter. Twitter, 22 April.

https://marketing.twitter.com/na/en/insights/covid19-gaming-conversation-trends

Cimino, Francesca; Besson, Léa (2020). Update: Covid-19 crisis PSM audience performance. Geneva: EBU. https://www.ebu.ch/publications/research/membersonly/report/covid-19-crisis-the-impact-on-digital-media-consumption

Cimino, Francesca; Hartmann, Florence; Besson, Léa; Speck, Dominik (2020). Covid-19 crisis PSM audience performance. Geneva: EBU.

https://www.ebu.ch/publications/research/membersonly/report/covid-19-crisis-psm-audience-performance

Costa-Sánchez, Carmen; López-García, Xosé (2020). “Comunicación y crisis del coronavirus en España. Primeras lecciones". El profesional de la información, v. 29, n. 3, e290304.

https://doi.org/10.3145/epi.2020.may.04

Curran, Noel (2020). Covid-19 crisis makes compelling case for digital transformation. EBU, 3 June. https://www.ebu.ch/news/2020/06/covid-19-crisis-makes-compelling-case-for-digital-transformation

De-Tender, Jean-Philip (2020). "Preface". In: Casebook, The digital transformation initiative. European Broadcasting Union.

https://www.ebu.ch/publications/strategic/membersonly/case-study/the-digital-transformation-casebook

De-Tender, Jean-Philip; Eeman, Ezra; Scott, Sasha; O’Sullivan, Eoghan; Zakka, Grace (2020). Casebook. The Digital Transformation Initiative. European Broadcasting Union.

https://www.ebu.ch/publications/strategic/membersonly/case-study/the-digital-transformation-casebook

EBU (2014). Public service values. Editorial principles and guidelines.

https://www.ebuc.ch/mis

EBU (2019). Funding of public service media 2019: Public version. EBU Media Intelligence Service.

https://www.ebu.ch/publications/research/members_only/report/funding-of-public-service-media-2019

EBU (2020a). Lessons from lockdown exploring childrens broadcasting. European Broadcasting Union.

https://www.ebu.ch/news/2020/05/ebu-lessons-from-lockdown-exploring-childrens-broadcasting

Video:

https://www.youtube.com/watch?v=6EKX-7-XfJY

EBU (2020b). Lessons from lockdown exploring sports broadcasting. European Broadcasting Union.

https://www.ebu.ch/news/2020/06/ebu-lessons-from-lockdown-exploring-sport-broadcasting

Video:

https://www.youtube.com/watch?v=fwwfmzz4quQ

EBU (2020c). The Digital Transformation Initiative (DTI) Casebook, 20 April.

https://www.ebu.ch/publications/strategic/membersonly/case-study/the-digital-transformation-casebook

EBU (2020d). Gender equality and diversity implications of Covid-19 crisis for public service media. EBU, April. https://www.ebu.ch/files/live/sites/ebu/files/Publications/strategic/open/COVID19\%20Gender\%20and\%20Diversity\%20 Implications\%20of\%20PSM\%20REPORT\%20April\%202020.pdf

Fernández-Quijada, David; Speck, Dominik (2020). Covid-19 crisis. Public radio response to the pandemic. Geneva: EBU. https://www.ebu.ch/publications/research/loginonly/report/covid-19-crisis-public-radio-response-to-the-pandemic

Freedman, Des (2016). Public service boradcasitng: when the status quo won't do. Media Policy Project Blog LSE. http://blogs.Ise.ac.uk/mediapolicyproject/2016/12/02/public-service-broadcasting-when-the-status-quo-wont-do/

Fuchs, Christian (2018). The online advertising tax as the foundation of a public service internet. London: University of Westminster Press.

Hallin, Daniel; Mancini, Paolo (2004). Comparing media systems. Three models of the media and politics. Cambridge: Cambridge University Press. ISBN: 9780521543088 
Howcroft, Chloe (2020). The financial impact of Covid-19 on European public broadcasters. Public Media Alliance. https://www.publicmediaalliance.org/the-financial-impacts-of-covid-19-on-european-public-broadcasters

Hutchinson, Jonathon (2017). Cultural intermediaries: Audience participation in media organisations. Palgrave Macmillan. https://doi.org/10.1007/978-3-319-66287-9

Iosifidis, Petros (2010). Retos y estrategias del servicio público de televisión en Europa. In: Infoamérica: Iberoamerican communication review, n. 3-4, pp. 7-21.

https://www.infoamerica.org/icr/n03_04/iosifidis.pdf

Jutkowitz, Mark; Michel, Amy (2020). Cable TV and Covid-19: how Americans perceive the outbreak and view-media coverage differ by main news source. Pew Research Center.

https://www.journalism.org/2020/04/01/cable-tv-and-covid-19-how-americans-perceive-the-outbreak-and-viewmedia-coverage-differ-by-main-news-source

Karppinen, Kari; Moe, Hallvard (2016). "What we talk about when talk about 'Media independence'". Javnost-The public, v. 23, n. 2, pp. 105-119.

https://doi.org/10.1080/13183222.2016.1162986

Radu, Raluca (2018). Europe's public service media: No common strategy. European Journalism Observatory, 14 August. https://en.ejo.ch/media-economics/europes-public-service-media-no-common-strategy

Robbins, Stephen; Judge, Tymothy A. (2009). Comportamiento organizacional, $13^{\text {rd }}$ ed. México: Pearson. ISBN: 978607 4420982

Rosenmeier, Cecilie (2020). Broadcast community sing-along gathers Danes through corona isolation. Denmark: DR, 2 April.

https://www.dr.dk/om-dr/about-dr/broadcast-community-sing-along-gathers-danes-through-corona-isolation

Scott, Sasha (2020). How is the crisis impacting digital transformation for PSM? Early insights. DTI, EBU.

https://www.ebu.ch/events/2020/05/digital-transformation-initiative--covid19-roundtable

SimilarWeb (2020). SimilarWeb Coronavirus Data \& Insights Hub.

https://www.similarweb.com/coronavirus

Speck, Dominik (2020). Market insights. Trust in media 2020. Geneva: EBU.

https://www.ebu.ch/publications/research/login_only/report/trust-in-media

Van-den-Bulck, Hilde; Broughton-Micova, Sally; Milosavljevic, Marko (2018). Screens engaged: Communication law and policy: issues of concern.

https://ecrea.eu/Newsletter/5980236

Vanhaeght, Anne-Sophie; Donders, Karen (2015). "Interaction, co-creation and participation in PSM literature, policy and strategy". Medijske studije, v. 6, n. 12, pp. 46-62.

https://hrcak.srce.hr/ojs/index.php/medijske-studije/article/view/6153

Vaz-Álvarez, Martín; Túñez-López, José-Miguel; Frazão-Nogueira, Ana-Gabriela (2020). “Co-creating value in European public service media". Cisti'2020, 15 Conferencia ibérica de sistemas y tecnologías de información.

http://www.aisti.eu/index.php/es/12-news/38-cisti-2017-12-conferencia-iberica-de-sistemas-y-tecnologias-de-informacion

\section{El profesional de la información \\ Servicio de traducciones al inglés}

http://www.elprofesionaldelainformacion.com/documentos/traducciones.pdf 